BORDER MATTERS 
AMERICAN CROSSROADS

Edited by Earl Lewis, George Lipsitz, Peggy Pascoe, George Sánchez, and Dana Takagi

I. Border Matters: Remapping American Cultural Studies, by José David Saldívar

2. The White Scourge: Mexicans, Blacks, and Poor Whites in Texas Cotton Culture, by Neil Foley 


\title{
BORDER MATTERS
}

\section{REMAPPING AMERICAN \\ CULTURAL STUDIES}

\author{
José David SAldívar
}

University of California Press

Berkeley Los Angeles London 
University of California Press

Berkeley and Los Angeles, California

University of California Press, Ltd.

London, England

(C) 1997 by the Regents of the University of California

Parts of the introduction appeared, in different form, in The American Literary History Reader, edited by Gordon Hutner (New York: Oxford University Press, 1995); parts of chapter I in The Columbia History of the American Novel: New Views, edited by Emory Elliott (New York: Columbia University Press, r993); most of chapter 2 in Cultures of U.S. Imperialism, edited by Amy Kaplan and Donald Pease (Durham, N.C.: Duke University Press, 1993), and in Blackwell's Companion to American Thought (Oxford: Blackwell, 1995); portions of chapter 3 in Confluencia I (Spring 1986); portions of chapter 4 in Stanford Magazine (September 1993); portions of chapter 5 in Mester I $2 / 13_{3}$ (Fall I993/ Spring 1994); and an early version of chapter 7 appeared in Revista Casa de las Américas (July-September I 996). Grateful acknowledgment is made for permission to reprint this material.

Library of Congress Cataloging-in-Publication Data Saldivar, José David.

Border matters : remapping American cultural studies / José David Saldívar.

p. cm. - (American crossroads ; I)

Includes bibliographical references and index.

ISBN 0-520-2068 I-9 (cloth : alk. paper). - ISBN 0-5202068 2-7 (pbk. : alk. paper)

r. Mexican-American Border Region-Civilization.

2. Popular culture-Mexican-American Border Region.

3. Mexican American arts-Mexican-American Border

Region. 4. American literature-Mexican American

authors-History and criticism. 5. Mexican-American

Border Region-Intellectual life. 6. Biculturalism-

Mexican-American Border Region. I. Title. II. Series.

F 787.S19 1997

$306^{\prime} .0972^{\prime} 1$-dc2 I

96-49209 CIP

Printed in the United States of America

98765432 I

The paper used in this publication meets the minimum requirements of American National Standard for Information Sciences-Permanence of Paper for Printed Library Materials, ANSI Z39.48-1984. 